\title{
The impact of body mass index on adaptive immune cells in the human bone marrow
}

\author{
Luca Pangrazzi ${ }^{1,2^{*}}$, Erin Naismith ${ }^{1}$, Carina Miggitsch ${ }^{1,3}$, Jose' Antonio Carmona Arana $^{1}$, Michael Keller ${ }^{1}$, \\ Beatrix Grubeck-Loebenstein ${ }^{1}$ and Birgit Weinberger ${ }^{1}$
}

\begin{abstract}
Background: Obesity has been associated with chronic inflammation and oxidative stress. Both conditions play a determinant role in the pathogenesis of age-related diseases, such as immunosenescence. Adipose tissue can modulate the function of the immune system with the secretion of molecules influencing the phenotype of immune cells. The importance of the bone marrow (BM) in the maintenance of antigen-experienced adaptive immune cells has been documented in mice. Recently, some groups have investigated the survival of effector/ memory T cells in the human BM. Despite this, whether high body mass index (BMI) may affect immune cells in the $\mathrm{BM}$ and the production of molecules supporting the maintenance of these cells it is unknown.

Methods: Using flow cytometry, the frequency and the phenotype of immune cell populations were measured in paired BM and PB samples obtained from persons with different BMI. Furthermore, the expression of BM cytokines was assessed. The influence of cytomegalovirus (CMV) on T cell subsets was additionally considered, dividing the donors into the $\mathrm{CMV}^{-}$and $\mathrm{CMV}^{+}$groups.

Results: Our study suggests that increased BMI may affect both the maintenance and the phenotype of adaptive immune cells in the BM. While the BM levels of IL-15 and IL-6, supporting the survival of highly differentiated T cells, and oxygen radicals increased in overweight persons, the production of IFNY and TNF by CD8 ${ }^{+} \mathrm{T}$ cells was reduced. In addition, the frequency of B cells and $\mathrm{CD}^{+}{ }^{+} \mathrm{T}$ cells positively correlated with BMI in the BM of $\mathrm{CMV}^{-}$ persons. Finally, the frequency of several $T$ cell subsets, and the expression of senescence/exhaustion markers within these subpopulations, were affected by BMI. In particular, the levels of bona fide memory T cells may be reduced in overweight persons.
\end{abstract}

Conclusion: Our work suggests that, in addition to aging and CMV, obesity may represent an additional risk factor for immunosenescence in adaptive immune cells. Metabolic interventions may help in improving the fitness of the immune system in the elderly.

Keywords: BMI, CMV, Human, Bone marrow, Peripheral blood, T cells

\footnotetext{
* Correspondence: Luca.Pangrazzi-1@unitn.it

'Department of Immunology, Institute for Biomedical Aging Research, University of Innsbruck, Rennweg, 10 Innsbruck, Austria

${ }^{2}$ Present Address: Center for Mind/Brain Sciences (CIMeC), University of

Trento, Corso Bettini, 31 Rovereto, Italy

Full list of author information is available at the end of the article
}

(c) The Author(s). 2020 Open Access This article is licensed under a Creative Commons Attribution 4.0 International License, which permits use, sharing, adaptation, distribution and reproduction in any medium or format, as long as you give appropriate credit to the original author(s) and the source, provide a link to the Creative Commons licence, and indicate if changes were made. The images or other third party material in this article are included in the article's Creative Commons licence, unless indicated otherwise in a credit line to the material. If material is not included in the article's Creative Commons licence and your intended use is not permitted by statutory regulation or exceeds the permitted use, you will need to obtain permission directly from the copyright holder. To view a copy of this licence, visit http://creativecommons.org/licenses/by/4.0/ The Creative Commons Public Domain Dedication waiver (http://creativecommons.org/publicdomain/zero/1.0/) applies to the data made available in this article, unless otherwise stated in a credit line to the data. 


\section{Introduction}

Obesity is characterized by excessive accumulation of subcutaneous adipose tissue and visceral fat, which impairs overall health and promotes the development of several pathologies, including age-related diseases. Indeed, high body mass index (BMI) has been associated with cardiovascular diseases, type 2 diabetes, insulin resistance, and tumors $[1,2]$. It has been shown that obesity is a cause of oxidative stress and chronic inflammation throughout the body, conditions which play a major role in the pathogenesis of diseases $[3,4]$. Increased levels of pro-inflammatory cytokines such as IL- 6 and TNF, and acute phase proteins have been documented in the peripheral blood (PB) of obese persons [5]. As adipose tissue and the immune system cooperate closely, either through the secretion of soluble mediators or after direct contact, accumulation of fat may influence the frequency and the phenotype of lymphocyte populations [6-8].

In the last years, several studies have demonstrated that the bone marrow (BM) plays an important role in the long-term maintenance of memory $\mathrm{T}$ cells and long-lived plasma cells [9-13]. In the elderly, the expression of proinflammatory molecules IFNY and TNF and the levels of reactive oxygen species (ROS) are high in the BM [14]. In this situation, the expression of IL-15 and IL-6, which support the survival of highly differentiated $\mathrm{CD}^{+} \mathrm{T}$ cell subsets in the BM, is additionally increased. Furthermore, in the presence of latent cytomegalovirus (CMV) infection, IL-15 expression, as well as the frequency of highly differentiated $\mathrm{CD} 28^{-} \mathrm{CCR}^{-} \mathrm{CD} 45 \mathrm{RA}{ }^{\text {bright }} \mathrm{CD}^{+} \mathrm{T}_{\mathrm{EMRA}}$ cells in the $\mathrm{BM}$, increase in comparisons to $\mathrm{CMV}$ seronegative persons [15].

Marrow adipose tissue (MAT) is located within the bone marrow microenvironment and is surrounded by hematopoietic and skeletal lineage cells. Subcutaneous white adipose tissue (WAT) is known to act as metabolic regulators, with the important functions of storing excess calories in the form of triglycerides and delivering fatty acids during fasting [16]. WAT additionally acts as endocrine organ, producing and secreting adipokines [17]. Recently, our lab described that MAT is characterized by elevated ROS levels and produces higher amounts of IL15, IL-6 and TNF, in comparison to white adipose tissue (WAT) [18]. Furthermore, BM adipocytes were shown to impair the function of plasma cells [18]. Increased marrow adiposity has been described with obesity, at least in mice [19], and an influence of MAT on immune cells present within the BM can be expected. Nevertheless, it is unknown whether body weight may affect the frequency and phenotype of immune cells present within the marrow environment, and the production of molecules supporting the maintenance of adaptive immune cells in the BM. In the current study, the impact of body weight on BM niches supporting the survival of adaptive immune cells, as well as on the frequency of immune cell subsets in the $\mathrm{BM}$, was assessed. In addition, the phenotype of $\mathrm{T}$ cell subsets was investigated in persons with different BMI, in both $\mathrm{BM}$ and $\mathrm{PB}$. As the phenotype and the frequency of $T$ cell subsets are strongly influenced by CMV, the comparisons were performed independently in $\mathrm{CMV}^{-}$and $\mathrm{CMV}^{+}$individuals. The expression of BM cytokines IL-15 and IL-6, known to support the survival of highly differentiated $\mathrm{CD} 8^{+} \mathrm{T}$ cells, and the levels of ROS, increased in overweight persons. The frequency of $\mathrm{B}$ cells, $\mathrm{CD} 4^{+} \mathrm{T}$ cells, as well as several $\mathrm{T}$ cell subsets were affected by BMI. In same cases, the changes in the BM were similar to the situation in the periphery. Thus, our work shows for the first time that body weight may affect both the maintenance and the phenotype of adaptive immune cells in the BM.

\section{Materials and methods Sample preparation}

Samples were obtained from systemically healthy individuals who did not suffer from diseases known to affect the immune system. The donors comprised of 72 individuals (37 females, 35 males) aged between 31 and 89 years (mean age: $69.7 \pm 12.9$ ) and BMI between 20.2 and 43.5 (mean BMI: $28.9 \pm 5.4$ ). 35 samples were CMV seronegative and 37 seropositive. No age differences were observed between the two groups (age $\mathrm{CMV}_{-}=69.8 \pm 11$ age $_{\mathrm{CMV}_{+}}=$ $69.6 \pm 13$ ), and no correlations $\mathrm{BMI} /$ age were identified within the groups $\left(\mathrm{r}_{\mathrm{s}} \mathrm{CMV}-=-0.15, p=0.44 ; \mathrm{r}_{\mathrm{S}} \mathrm{CMV}_{+}=-\right.$ $0.10, p=0.51)$. The number of samples used in individual experiments is given in the figures and legends. For the isolation of bone marrow mononuclear cells (BMMCs), a fragment of substantia spongiosa osseum, which would otherwise be discarded, was collected during routine hip replacement surgery. The bone was further fragmented and treated with purified collagenase solution, constituted by the combination of a sulfhydryl protease (clostripain) and an aminopeptidase (CLSPA, Worthington Biochemical; $20 \mathrm{U} / \mathrm{ml}$ ), in complete RPMI medium (RPMI 1640, Corning supplemented with $10 \% \mathrm{FCS}, 100 \mathrm{U} / \mathrm{ml}$ penicillin, and $100 \mu \mathrm{g} / \mathrm{ml}$ streptomycin, Sigma) for $1 \mathrm{~h}$ at $37^{\circ} \mathrm{C}$. BMMCs were extracted using a filtered tube centrifugation step, and then purified using density gradient centrifugation (Lymphoprep ${ }^{\circ}$, Stemcell technologies). Paired samples of heparinised blood from the same donors were collected, and peripheral blood mononuclear cells (PBMCs) were purified by density gradient centrifugation.

\section{Cell culture and flow cytometric analysis}

Immunofluorescence surface staining was performed by adding a panel of directly conjugated.

Abs to freshly prepared BMMCs and PBMCs. Dead cells were excluded from the analysis using a viability 
dye (Zombie AquaFixable viability dye or 7-AAD). After surface staining, cells were permeabilized using the Cytofix/Cytoperm kit (BD Pharmingen), and incubated with intracellular Abs. Cells were washed and measured using a FACSCanto II (BD Biosciences). Flow cytometry data were analysed using FlowJo v10 software.

To analyze IFN $\gamma$ and TNF production, both BMMCs and PBMCs were stimulated for $4 \mathrm{~h}$ at $37^{\circ} \mathrm{C}$ with $30 \mathrm{ng} /$ $\mathrm{ml}$ PMA and $500 \mathrm{ng} / \mathrm{ml}$ ionomycin in the presence of $10 \mathrm{mg} / \mathrm{ml}$ brefeldin A (BFA; Sigma Aldrich). The production of IL-15 and IL- 6 was assessed as previously described [14]. In summary, BMMCs were incubated for $12 \mathrm{~h}$ in the presence of $10 \mathrm{mg} / \mathrm{ml}$ brefeldin A. IL-15 and IL-6 mean fluorescence intensity (MFI) was measured with intracellular staining in the whole BMMC population.

The complete list of antibodies used for the experiments is shown in Suppl. Table 1.

\section{Measurement of ROS}

BMMCs and PBMCs were incubated with the fluorescent dye dihydroethidium (Sigma-Aldrich) at a concentration of 1:250 in complete RPMI for $20 \mathrm{~min}$ at $37^{\circ} \mathrm{C}$. Cells were washed in PBS and measured with a FACSCanto II.

\section{Determination of CMV seropositivity}

Antibodies against CMV were determined in the plasma of the donors included in the study using a commercially available ELISA Kit (Siemens).

\section{Statistical analysis}

Spearman correlations were used to determine the statistical significance as indicated in the figure legends. Comparisons between groups were assessed with unpaired two-tailed $t$ tests. Comparisons between $\mathrm{PB}$ and $\mathrm{BM}$ were performed with paired two tailed $\mathrm{t}$ tests. $p$ values less than 0.05 were considered significant.

\section{Results}

Production of BM cytokines and reactive oxygen species (ROS) change with increased BMI

The BM microenvironment, which plays an important role in the maintenance of antigen-experienced adaptive immune cells, changes with age and CMV $[14,15]$. To assess whether the BMI may also affect BM niches, the production of BM cytokines was measured in the BM of persons with different body weight (Fig. 1). The expression of both IL-15 and IL- 6 in BMMCs was higher in the group $\mathrm{BMI}>30$, in comparison with lean persons $(\mathrm{BMI}<25)$ (Fig. 1a-b). Levels of ROS and the proinflammatory molecules IFN $\gamma$ and TNF increase in the

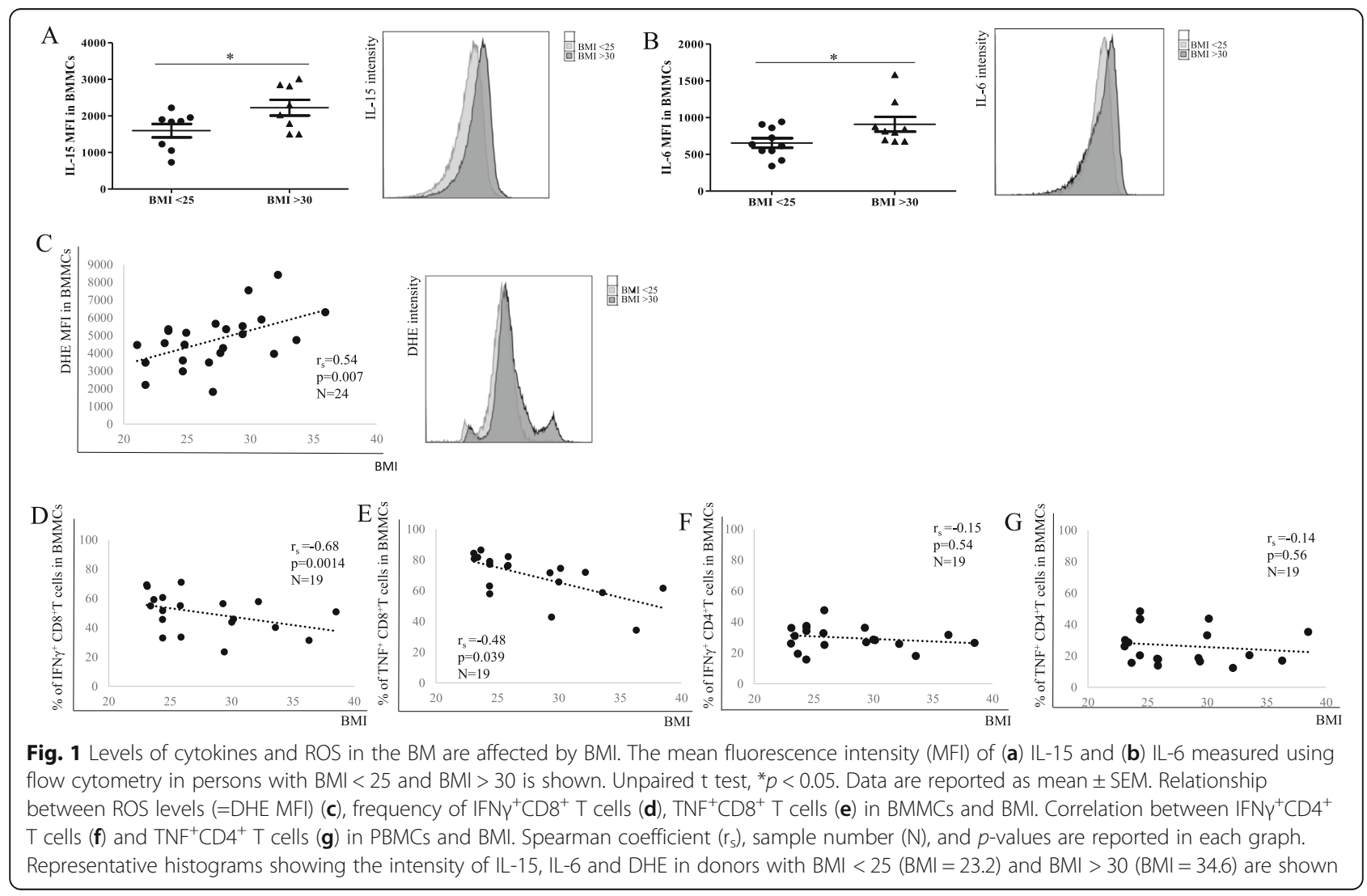


BM with age [12]. When BMI was put in relationship with ROS levels in the BM, increased oxygen radicals were found in persons with higher body weight (Fig. 1c). Furthermore, reduced production of IFNY and TNF by $\mathrm{CD}^{+} \mathrm{T}$ cells, but not by $\mathrm{CD} 4^{+} \mathrm{T}$ cells, was observed with higher BMI (Fig. 1d-g). No correlation was found between BMI and ROS levels, IFNY ${ }^{+}$and $\mathrm{TNF}^{+} \mathrm{CD}^{+} \mathrm{T}$ cells in PBMCs (Suppl. Fig. 1). Representative FACS plots showing IFN $\gamma^{+}$and $\mathrm{TNF}^{+} \mathrm{CD}^{+} \mathrm{T}$ cells in a lean and an obese donor in paired BM and PB samples are reported in Suppl. Fig. 2. Our results indicate that the expression of molecules supporting the maintenance of late differentiated adaptive immune cells in the BM and the production of $\mathrm{T}$ cell cytokines change in the $\mathrm{BM}$ with increased BMI.

\section{Immune cell populations are affected by BMI in the BM}

Associations between immune parameters and BMI have been described in the PB [8]. Whether immune cell populations in the BM change with increased body weight is unknown. As CMV is known to affect the phenotype of immune cells, we assessed the frequency of populations in BMMCs from CMV seronegative and seropositive persons in correlation with BMI (Table 1). The gating strategy for the populations included in the analysis is shown in Fig. 2. While natural killer (NK), natural killer $\mathrm{T}$ (NKT) cells, monocytes and plasma cells did not change, the overall B cell frequency in the BM increased with BMI in $\mathrm{CMV}^{-}$persons (Table 1). No differences were observed for $\mathrm{CMV}^{+}$donors, although $\mathrm{B}$ cell levels were similar in $\mathrm{CMV}^{-}$and $\mathrm{CMV}^{+}$persons (Suppl Fig. 3 A). While the levels of $\mathrm{T}$ cells and $\mathrm{CD}^{+} \mathrm{T}$ cells did not differ when overweight and lean persons were compared,

Table 1 Correlations of immune cell populations in in the human BM with BMI

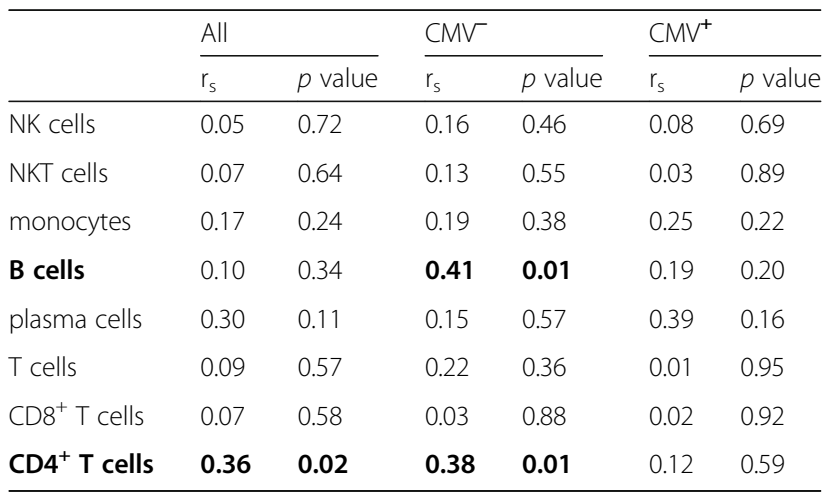

Spearman correlation coefficients $\left(r_{\mathrm{s}}\right)$ and $p$ values for $\mathrm{CMV}^{-}$and $\mathrm{CMV}^{+}$ persons and for the whole cohort are shown. $p<0.05$ was considered significant. For NK, NKT, monocytes, T cells, $\mathrm{CD}^{+}$and $\mathrm{CD}^{+}{ }^{+} \mathrm{T}$ cells $\mathrm{N}_{\mathrm{CMV}}{ }^{-}=30$, $\mathrm{N}_{\mathrm{CMV}}{ }^{+}=35, \mathrm{~N}_{\mathrm{all}}=65$, for $\mathrm{B}$ cells and plasma cells $\mathrm{N}_{\mathrm{CMV}}{ }^{-}=19, \mathrm{~N}_{\mathrm{CMV}}{ }^{+}=22, \mathrm{~N}_{\text {all }}=$ 41 (part of the same cohort). NK cells are defined as $\mathrm{CD}^{-} \mathrm{CD}^{-} 6^{+}$, $\mathrm{T}$ cells as $\mathrm{CD}^{+}$, NKT cells as $\mathrm{CD}^{+} \mathrm{CD} 56^{+}$, monocytes as CD14 ${ }^{+}$and $\mathrm{B}$ cells as $\mathrm{CD} 19^{+}$ leukocytes. Plasma cells are defined as CD $38^{\text {hi }} \mathrm{CD} 138^{+} \mathrm{B}$ cells. Detailed gating strategy is shown in Fig. 2

Statistically significant values are shown in bold the frequency of $\mathrm{CD} 4^{+} \mathrm{T}$ cells increased with $\mathrm{BMI}$ in $\mathrm{CMV}^{-}$persons. Again, similar levels of $\mathrm{CD}^{+} \mathrm{T}$ cells were found in $\mathrm{CMV}^{-}$and $\mathrm{CMV}^{+}$persons (Suppl Fig. 3 $\mathrm{B})$, but no significant correlations between BMI and $\mathrm{CD}^{+}{ }^{+} \mathrm{T}$ cells were observed for $\mathrm{CMV}^{+}$donors.

In summary, although most of the immune cell populations in the $\mathrm{BM}$ were not affected, $\mathrm{B}$ cells and $\mathrm{CD} 4^{+} \mathrm{T}$ cells positively correlated with BMI, at least in $\mathrm{CMV}^{-}$ persons.

\section{$\mathrm{CD}^{+} \mathrm{T}$ cell subsets change with BMI}

We then aimed to investigate whether $\mathrm{CD} 4^{+} \mathrm{T}$ cell subpopulations may change with increased BMI, in both BMMCs and PBMCs (Table 2 and Suppl. Table 2). Gating strategy used to define the subsets of interest using flow cytometry is shown in Fig. 3. Using the markers CCR7 and CD45RA, we defined the four populations $\mathrm{CCR}^{+} \mathrm{CD} 45 \mathrm{RA}^{+}$naïve $\left(\mathrm{T}_{\mathrm{N}}\right), \mathrm{CCR}^{+} \mathrm{CD} 45 \mathrm{RA}^{-}\left(\mathrm{T}_{\mathrm{CM}}\right)$, $\mathrm{CCR7}^{-} \mathrm{CD}^{2} 5 \mathrm{RA}^{-}\left(\mathrm{T}_{\mathrm{EM}}\right)$ and $\mathrm{CCR}^{-} \mathrm{CD}^{-} 5 \mathrm{RA}^{+}$( $\mathrm{T}_{\text {EMRA }}$ ) within $\mathrm{CD}^{+}{ }^{+} \mathrm{T}$ cells (Fig. 3). Interestingly, in the BM but not in the $\mathrm{PB}$ of $\mathrm{CMV}^{+}$persons, $\mathrm{CD}^{+} \mathrm{T}_{\mathrm{N}}, \mathrm{CD}^{+} \mathrm{T}_{\mathrm{CM}}$ and $\mathrm{CD} 4^{+} \mathrm{T}_{\mathrm{EMRA}}$ were positively associated, while $\mathrm{CD} 4^{+}$ $\mathrm{T}_{\mathrm{EM}}$ negatively correlated to BMI. In addition, in $\mathrm{CMV}^{-}$ donors, the frequency of $\mathrm{CD} 4^{+} \mathrm{T}_{\mathrm{EMRA}}$ were higher in overweight persons. No differences were found for $\mathrm{CD} 4^{+} \mathrm{CD} 28^{-}$and $\mathrm{CD} 4^{+} \mathrm{CD} 57^{+} \mathrm{T}$ cells, neither in BMMCs nor in PBMCs. PD-1 is overexpressed in activated and/or exhausted T cells [20]. PD-1 expression in the whole $\mathrm{BM} \mathrm{CD} 4^{+} \mathrm{T}$ cell population and in $\mathrm{CD} 4^{+} \mathrm{T}_{\mathrm{EM}}$ cells negatively correlated with BMI, specifically in $\mathrm{CMV}^{-}$persons. IL-7R $\alpha$ expression on $\mathrm{T}$ cells is a marker for responsiveness to the $\mathrm{T}$ cell cytokine IL-7. Within $\mathrm{CD} 4^{+} \mathrm{T}$ cells, IL-7R $\alpha$ was found to be increased with higher BMI. No differences were observed when the expression of PD-1 and IL-7R $\alpha$ was assessed in the periphery (Suppl. Table 2).

Taken together, our results indicate that, with increased BMI, the frequency and the phenotype of several $\mathrm{CD}^{+} \mathrm{T}$ cell subsets change in the $\mathrm{BM}$, although no differences are present in the $\mathrm{PB}$.

\section{$\mathrm{CD}^{+} \mathrm{T}$ cell subsets change with $\mathrm{BMI}$}

We next assessed whether $\mathrm{CD}^{+} \mathrm{T}$ cell subsets in the BM may additionally change with increased body weight (Table 3). Again, $\mathrm{CD}^{+} \mathrm{T}_{\mathrm{N}}, \mathrm{T}_{\mathrm{CM}}, \mathrm{T}_{\mathrm{EM}}$ and $\mathrm{T}_{\mathrm{EMRA}}$ subpopulations were gated using the markers CCR7 and CD45RA. While the frequency of $\mathrm{CD}^{+} \mathrm{T}_{\mathrm{CM}}$ cells in the $\mathrm{BM}$ negatively correlated with $\mathrm{BMI}$ in $\mathrm{CMV}^{-}$persons, $\mathrm{CD}^{+} \mathrm{T}_{\mathrm{EM}}$ cells decreased with increased body weight only in $\mathrm{CMV}^{+}$donors (Table 3 ). No significant differences were observed for $\mathrm{CD}^{+} \mathrm{T}_{\mathrm{N}}$ and $\mathrm{CD} 8^{+} \mathrm{T}_{\text {EMRA }}$ cells. When the levels of the four subsets were measured in paired $\mathrm{PBMC}$ samples, $\mathrm{CD} 8^{+} \mathrm{T}_{\mathrm{EM}}$ were highly reduced in the $\mathrm{CMV}^{-}$group with increased BMI, but 


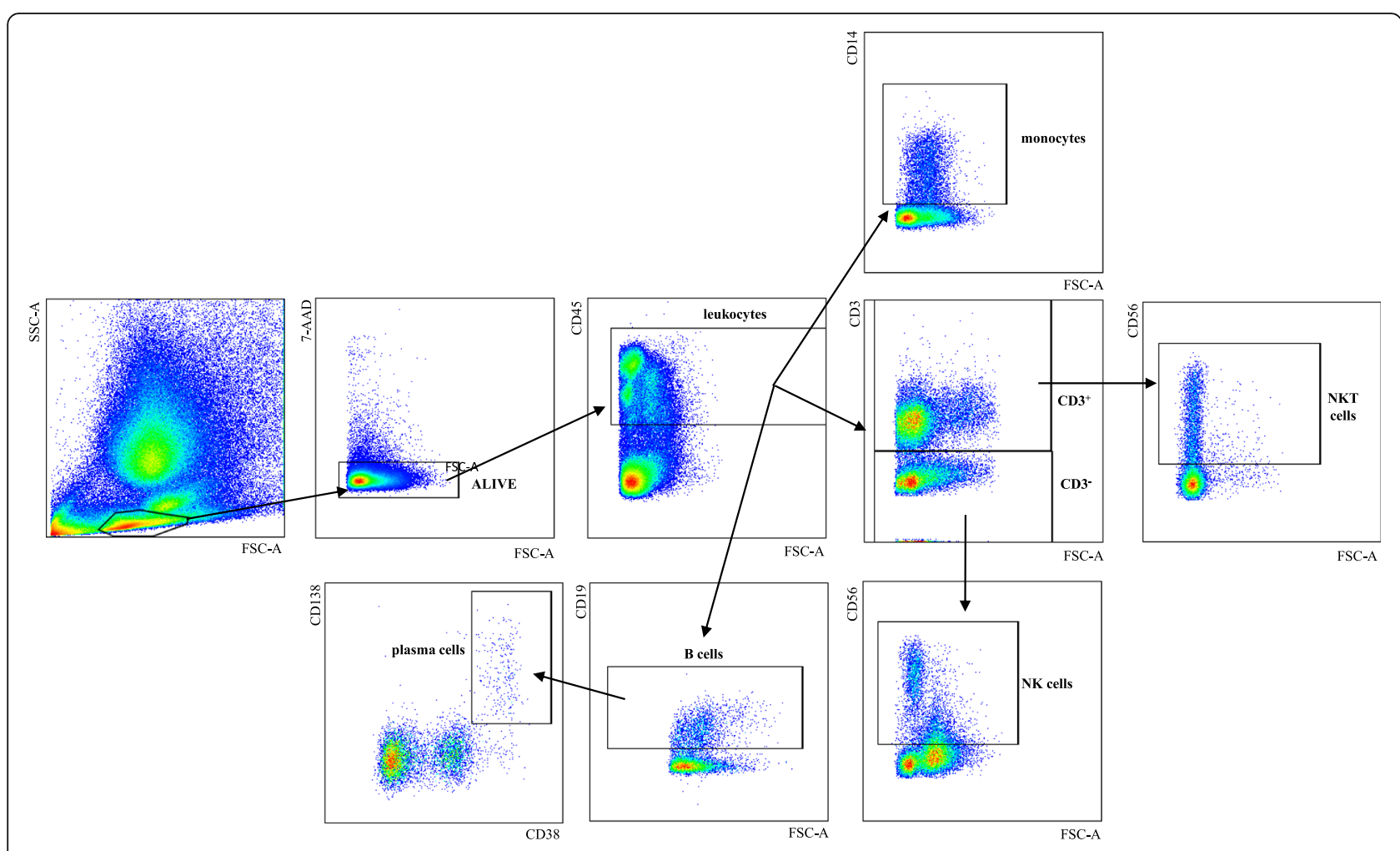

Fig. 2 Gating strategy for the population of interest. Representative FACS plot with the gating strategy for monocytes, T cells, NKT cells, NK cells, B cells and plasma cells are shown

Table 2 Correlations between CD4 ${ }^{+}$T cell subsets, expression of PD-1 and IL-7Ra within CD4 ${ }^{+}$T cell subsets in the BM and BMI

\begin{tabular}{|c|c|c|c|c|c|c|}
\hline & \multicolumn{2}{|l|}{ All } & \multicolumn{2}{|l|}{$\mathrm{CMV}^{-}$} & \multicolumn{2}{|l|}{$\mathrm{CMV}^{+}$} \\
\hline & $r_{s}$ & $p$ value & $r_{5}$ & $p$ value & $r_{s}$ & $p$ value \\
\hline $\mathrm{CD}^{+} \mathrm{T}$ cells (of $\mathrm{CD}^{+}$) & 0.36 & 0.02 & 0.38 & 0.01 & 0.12 & 0.59 \\
\hline $\mathrm{CCR7}^{+} \mathrm{CD} 4 \mathrm{RA}^{+}\left(\mathrm{CD}^{+} \mathrm{T}_{\mathrm{N}}\right)$ & 0.45 & 0.002 & 0.23 & 0.35 & 0.51 & 0.02 \\
\hline $\mathrm{CCR7}^{+} \mathrm{CD}^{2} 5 \mathrm{RA}^{-}\left(\mathrm{CD} 4^{+} \mathrm{T}_{\mathrm{CM}}\right)$ & 0.34 & 0.03 & -0.18 & 0.46 & 0.59 & 0.01 \\
\hline $\mathrm{CCR7}^{-} \mathrm{CD}^{2} 5 \mathrm{RA}^{-}\left(\mathrm{CD} 4^{+} \mathrm{T}_{\mathrm{EM}}\right)$ & -0.03 & 0.87 & -0.15 & 0.53 & -0.58 & 0.01 \\
\hline $\mathrm{CCR7}^{-} \mathrm{CD}^{2} 5 \mathrm{RA}^{+}\left(\mathrm{CD4}^{+}{ }_{\text {TEMRA }}\right)$ & 0.34 & 0.05 & 0.43 & 0.04 & 0.41 & 0.05 \\
\hline $\mathrm{CD} 4^{+} \mathrm{CD} 28^{-}$ & -0.02 & 0.91 & -0.16 & 0.50 & -0.01 & 0.96 \\
\hline $\mathrm{CD}^{+} \mathrm{CD} 7^{+}$ & 0.00 & 1.00 & 0.16 & 0.42 & 0.27 & 0.91 \\
\hline $\mathrm{CD}^{+}{ }^{+} \mathrm{PD}-1^{+}$ & -0.20 & 0.73 & -0.41 & 0.04 & -0.39 & 0.08 \\
\hline $\mathrm{CD}^{+} \mathrm{IL}-7 \mathrm{Ra}^{+}$ & 0.43 & 0.03 & 0.37 & 0.12 & 0.03 & 0.91 \\
\hline $\mathrm{PD}-1^{+} \mathrm{CD} 4^{+} \mathrm{T}_{\mathrm{CM}}$ & -0.36 & 0.02 & -0.21 & 0.39 & -0.22 & 0.34 \\
\hline $\mathrm{PD}-1^{+} \mathrm{CD} 4^{+} \mathrm{T}_{\mathrm{EM}}$ & -0.39 & 0.01 & -0.49 & 0.03 & -0.16 & 0.48 \\
\hline $\mathrm{CD} 57^{+} \mathrm{CD} 4^{+} \mathrm{T}_{\mathrm{EM}}$ & -0.19 & 0.22 & -0.02 & 0.93 & 0.14 & 0.55 \\
\hline $\mathrm{PD}-1^{+} \mathrm{CD} 4^{+} \mathrm{T}_{\text {EMRA }}$ & -0.33 & 0.10 & -0.19 & 0.44 & 0.01 & 0.97 \\
\hline $\mathrm{CD} 7^{+} \mathrm{CD} 4^{+} \mathrm{T}_{\text {EMRA }}$ & -0.03 & 0.85 & -0.01 & 0.98 & 0.19 & 0.39 \\
\hline
\end{tabular}

Spearman correlation coefficients $\left(\mathrm{r}_{\mathrm{s}}\right)$ and $p$ values for $\mathrm{CMV}^{-}$and $\mathrm{CMV}^{+}$persons and for the whole cohort are shown. $p<0.05$ was considered significant. For all subpopulations, $\mathrm{N}_{\mathrm{CMV}}{ }^{-}=20, \mathrm{~N}_{\mathrm{CMV}}{ }^{+}=19, \mathrm{~N}_{\mathrm{all}}=39$. Detailed gating strategy used to define the populations are shown in Fig. 3

Statistically significant values are shown in bold 


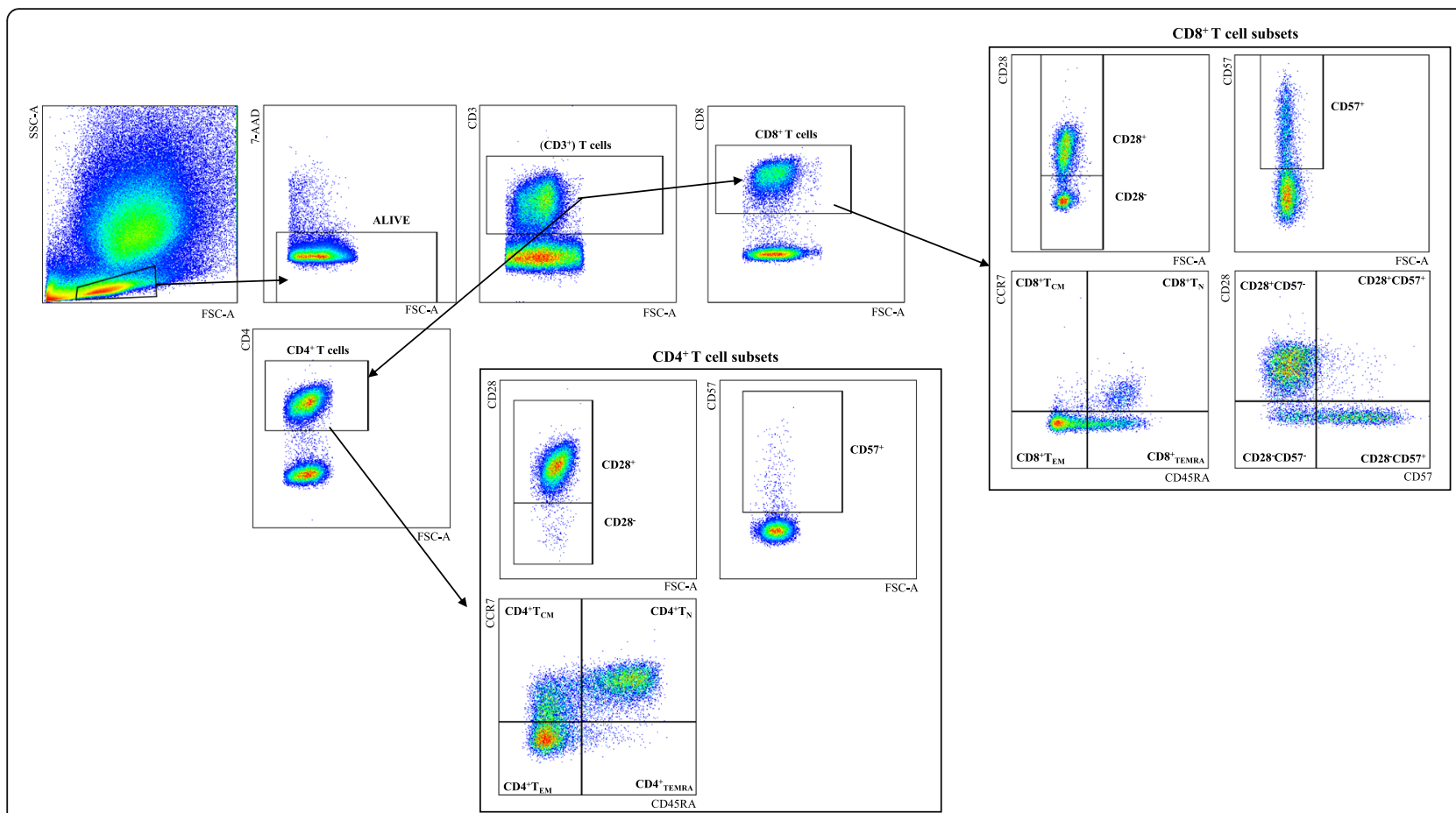

Fig. 3 Gating strategy for the subsets of interest within $C D 4^{+}$and $C D 8^{+}$T cells. Representative FACS plot with the gating strategy for CD28 ${ }^{+/-}$,

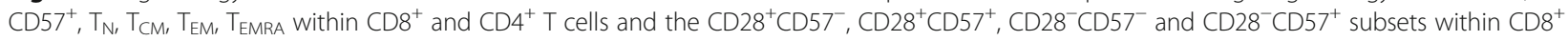
T cells are shown

$\mathrm{CD} 8^{+} \mathrm{T}_{\mathrm{CM}}$ cells, as well as $\mathrm{CD} 8^{+} \mathrm{T}_{\mathrm{EMRA}}$ cells did not change in overweight compared to lean persons (Suppl. Table 3). A positive correlation between frequency of $\mathrm{CD}^{+} \mathrm{T}_{\mathrm{N}}$ cells and BMI was also observed in the PB. With the markers $\mathrm{CD} 28$ and $\mathrm{CD} 57$, the populations $\mathrm{CD} 28^{-}, \mathrm{CD}^{2} 7^{+}$, as well as $\mathrm{CD} 28^{+} \mathrm{CD} 57^{-}, \mathrm{CD} 28^{+} \mathrm{CD} 57^{+}$, $\mathrm{CD} 28^{-} \mathrm{CD} 57^{-}$and $\mathrm{CD} 28^{-} \mathrm{CD} 57^{+}$were gated within
$\mathrm{CD}^{+} \mathrm{T}$ cells in BMMCs (Fig. 2). Only in $\mathrm{CMV}^{-}$persons, the $\mathrm{CD} 28^{+} \mathrm{CD} 57^{-}$and $\mathrm{CD} 28^{+} \mathrm{CD} 57^{+}$subsets negatively correlated, while $\mathrm{CD} 28^{-} \mathrm{CD} 57^{-}$cells were positively associated with BMI (Table 3 ). No significant differences were found for the $\mathrm{CD} 28^{-} \mathrm{CD} 57^{+}$subset. Similar results were found in PBMCs for $\mathrm{CD} 28^{+} \mathrm{CD} 57^{+}$ and $\mathrm{CD} 28^{-} \mathrm{CD} 57^{-}$cells, while no changes were observed

Table 3 Correlations of $\mathrm{CD}^{+} \mathrm{T}$ cell subsets in in the human BM with BMl

\begin{tabular}{|c|c|c|c|c|c|c|}
\hline & \multicolumn{2}{|l|}{ All } & \multicolumn{2}{|l|}{$\mathrm{CMV}^{-}$} & \multicolumn{2}{|l|}{$\mathrm{CMV}^{+}$} \\
\hline & $\mathrm{r}_{\mathrm{s}}$ & $p$ value & rs & $p$ value & rs & $p$ value \\
\hline $\mathrm{CD}^{+} \mathrm{T}$ cells & -0.07 & 0.58 & -0.03 & 0.88 & -0.02 & 0.92 \\
\hline $\mathrm{CCR7}^{+} \mathrm{CD} 4 \mathrm{RA}^{+}\left(\mathrm{CD}^{+} \mathrm{T}_{\mathrm{N}}\right)$ & 0.25 & 0.10 & 0.00 & 0.72 & 0.34 & 0.10 \\
\hline $\mathrm{CCR7}^{+} \mathrm{CD} 4 \mathrm{RA}^{-}\left(\mathrm{CD}^{+} \mathrm{T}_{\mathrm{CM}}\right)$ & -0.03 & 0.78 & -0.42 & 0.05 & -0.03 & 0.88 \\
\hline $\mathrm{CCR7}^{-} \mathrm{CD}^{2} 5 \mathrm{RA}^{-}\left(\mathrm{CD8}^{+} \mathrm{T}_{\mathrm{EM}}\right)$ & -0.34 & 0.02 & -0.24 & 0.27 & -0.41 & 0.05 \\
\hline $\mathrm{CCR7}^{-} \mathrm{CD} 45 \mathrm{RA}^{+}\left(\mathrm{CD}^{+}{ }^{+}\right.$TEMRA $)$ & 0.08 & 0.61 & 0.23 & 0.30 & 0.01 & 0.94 \\
\hline $\mathrm{CD}^{+} \mathrm{CD} 7^{+}$ & -0.32 & 0.01 & -0.33 & 0.05 & -0.27 & 0.19 \\
\hline $\mathrm{CD} 8^{+} \mathrm{CD} 28^{-}$ & -0.18 & 0.23 & -0.06 & 0.78 & -0.11 & 0.62 \\
\hline $\mathrm{CD}^{+} \mathrm{CD}_{28}^{+} \mathrm{CD}^{-} 7^{-}$ & -0.21 & 0.13 & -0.34 & 0.04 & -0.16 & 0.44 \\
\hline $\mathrm{CD}^{+} \mathrm{CD}_{28}^{+} \mathrm{CD}^{+} 7^{+}$ & -0.19 & 0.16 & -0.41 & 0.02 & 0.09 & 0.67 \\
\hline $\mathrm{CD}^{+} \mathrm{CD} 28^{-} \mathrm{CD} 57^{-}$ & 0.36 & 0.01 & 0.44 & 0.01 & 0.25 & 0.22 \\
\hline $\mathrm{CD}^{+}{ }^{+} \mathrm{CD} 28^{-} \mathrm{CD} 57^{+}$ & -0.18 & 0.17 & -0.05 & 0.76 & -0.27 & 0.17 \\
\hline
\end{tabular}

Spearman correlation coefficients $\left(\mathrm{r}_{\mathrm{s}}\right)$ and $p$ values for $\mathrm{CMV}^{-}$and $\mathrm{CMV}^{+}$persons and for the whole cohort are shown. $\mathrm{p}<0.05$ was considered significant. For all subpopulations, $\mathrm{N}_{\mathrm{CMV}}{ }^{-}=33, \mathrm{~N}_{\mathrm{CMV}}{ }^{+}=26, \mathrm{~N}_{\mathrm{all}}=59$. Detailed gating strategy used to define the populations is shown in Fig. 3

Statistically significant values are shown in bold 
for the other two subsets (Suppl. Table 3). Taken together, our data show that several $\mathrm{CD}^{+} \mathrm{T}$ cell populations change in the BM with increased BMI, particularly in the absence of CMV. Overall, the frequency of memory $\mathrm{CD}^{+} \mathrm{T}$ cells may be reduced in overweight compared to lean persons, while highly differentiated $\mathrm{CD} 28^{-} \mathrm{CD}^{-} 7^{-} \mathrm{CD} 8^{+} \mathrm{T}$ cells increase.

\section{The phenotype of $\mathrm{CDB}^{+} \mathrm{T}$ cell subsets change with BMI}

To investigate whether, in parallel with their frequency, the phenotype of $\mathrm{CD}^{+} \mathrm{T}$ cell subsets may change with increased body weight, the expression of molecules involved in $\mathrm{T}$ cell activation/exhaustion, responsiveness to $\mathrm{T}$ cell cytokines and memory as well as senescence was measured in paired BMMC and PBMC samples using flow cytometry (Table 4 and Suppl. Table 4). Representative FACS plots are shown in Suppl. Fig. 4. In the whole $\mathrm{CD}^{+} \mathrm{T}$ cell population in the BM, PD-1 was reduced in overweight compared to lean persons only in the $\mathrm{CMV}^{-}$group (Table 4). While no correlation was found between PD-1 expression within $\mathrm{CD}^{+} \mathrm{T}_{\mathrm{CM}}$ and $\mathrm{CD}^{+} \mathrm{T}_{\mathrm{EMRA}}$ cells and BMI, reduced levels of this molecule could be observed in the $\mathrm{CD} 8^{+} \mathrm{T}_{\mathrm{EM}}$ subset with higher body weight in $\mathrm{CMV}^{-}$persons. When the four

Table 4 Correlations between expression of PD-1, IL-7Ra and KLRG-1 within $\mathrm{CD}^{+} \mathrm{T}$ cell subsets in the human BM with BM

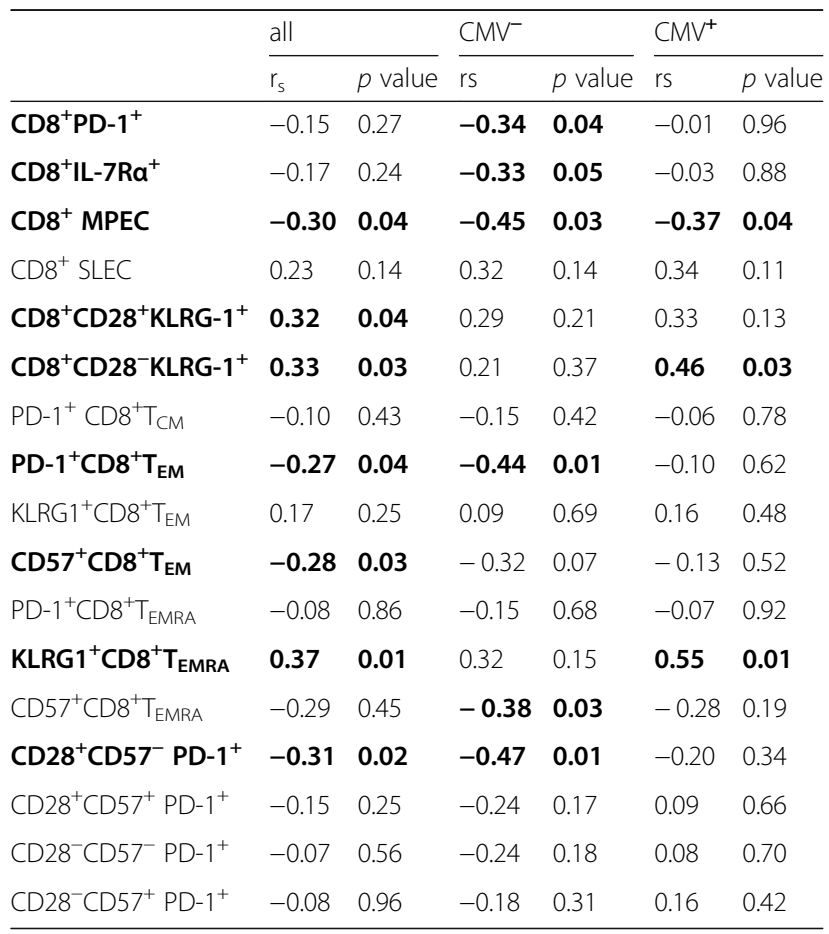

Spearman correlation coefficients $\left(r_{\mathrm{s}}\right)$ and $p$ values for $\mathrm{CMV}^{-}$and $\mathrm{CMV}^{+}$ persons and for the whole cohort are shown. $p<0.05$ was considered significant. For all subpopulations, $\mathrm{N}_{\mathrm{CMV}}{ }^{-}=33, \mathrm{~N}_{\mathrm{CMV}}{ }^{+}=26, \mathrm{~N}_{\text {all }}=59$. Detailed gating strategy used to define the populations and representative FACS plots are shown in Fig. 3 and Supplementary Fig. 3

Statistically significant values are shown in bold
$\mathrm{CD} 28^{+/-} \mathrm{CD} 57^{+/-}$subsets were considered, the negative correlation between PD-1 expression and BMI was shown in $\mathrm{CD}_{28}{ }^{+} \mathrm{CD} 57^{-} \mathrm{CD} 8^{+} \mathrm{T}$ cells, but not in the other subpopulations. Similar results were obtained in the PB (Suppl. Table 4). Again, PD-1 levels within CD8 ${ }^{+}$ $\mathrm{T}$ cell subsets were negatively associated to BMI. In the whole $\mathrm{CD} 8^{+} \mathrm{T}$ cell population in the $\mathrm{BM}$, the expression of IL-7R $\alpha$ negatively correlated with $\mathrm{BMI}$ in $\mathrm{CMV}^{-}$persons (Table 4). In $\mathrm{CMV}^{+}$persons, overall levels were lower in comparison to $\mathrm{CMV}^{-}$individuals (data not shown). The same results could be found in paired PBMC samples (Suppl. Table 4). The combination of the markers IL-7R $\alpha$ and KLRG-1 within $\mathrm{CD} 8^{+} \mathrm{T}$ cells allows the definition of IL-7R $\alpha^{+} \mathrm{KLRG}^{-} 1^{-}$memory progenitor effector cells (MPEC), which are known to differentiate into memory cells, and IL-7R $\alpha^{-} \mathrm{KLRG}^{-} 1^{+}$short living effector cells (SLEC), which may either die or accumulate as senescent-like T cells $[21,22]$. In the BM of both $\mathrm{CMV}^{-}$and $\mathrm{CMV}^{+}$persons, MPEC were negatively associated with BMI, while the levels of SLEC did not change. In the PB, MPEC decreased in donors with higher BMI only in the $\mathrm{CMV}^{+}$group (Suppl. Table 4). Interestingly, the expression of KLRG-1, commonly associated with terminally differentiated cells [23], positively correlated with BMI when its expression was measured within $\mathrm{CD} 8^{+} \mathrm{CD} 28^{-}$and $\mathrm{CD} 8^{+} \mathrm{T}_{\mathrm{EMRA}}$ cells in $\mathrm{CMV}^{+}$persons. Similar results could be obtained for the PB (Suppl. Table 4). A summary about correlations regarding $\mathrm{CD}^{+} \mathrm{T}$ cell subsets which were significant in both $\mathrm{BM}$ and $\mathrm{PB}$ is shown in Fig. 4. Representative FACS plots summarizing the differences between lean and obese donors in paired $\mathrm{BM}$ and $\mathrm{PB}$ samples are shown in Suppl. Fig. 5.

In summary, our results indicate that responsiveness to IL-7 and expression of PD-1 and KLRG-1 change with increased BMI, in both $\mathrm{BM}$ and $\mathrm{PB}$. In addition, memory $\mathrm{CD}^{+} \mathrm{T}$ cells may be reduced in overweight persons.

\section{Discussion}

Whether obesity may be considered a disease is still under debate [24]. Despite this, it is now evident that increased body weight is linked to a broad spectrum of diseases, which overall reduce healthspan in the elderly. Several studies showed that immune cell types such as macrophages, innate lymphoid cells, $\mathrm{T}$ cells and $\mathrm{B}$ cells are contained within the adipose tissue [25-28]. In particular, lymphoid cells such as NK cells, NKT, and B and $\mathrm{T}$ cells may play a fundamental role in the inflammatory process associated with obesity. Among the different types of adipose tissues present in the body, MAT has recently gained considerable importance in the field of immunological memory [18]. In our lab, we recently reported that MAT can produce survival factors for 


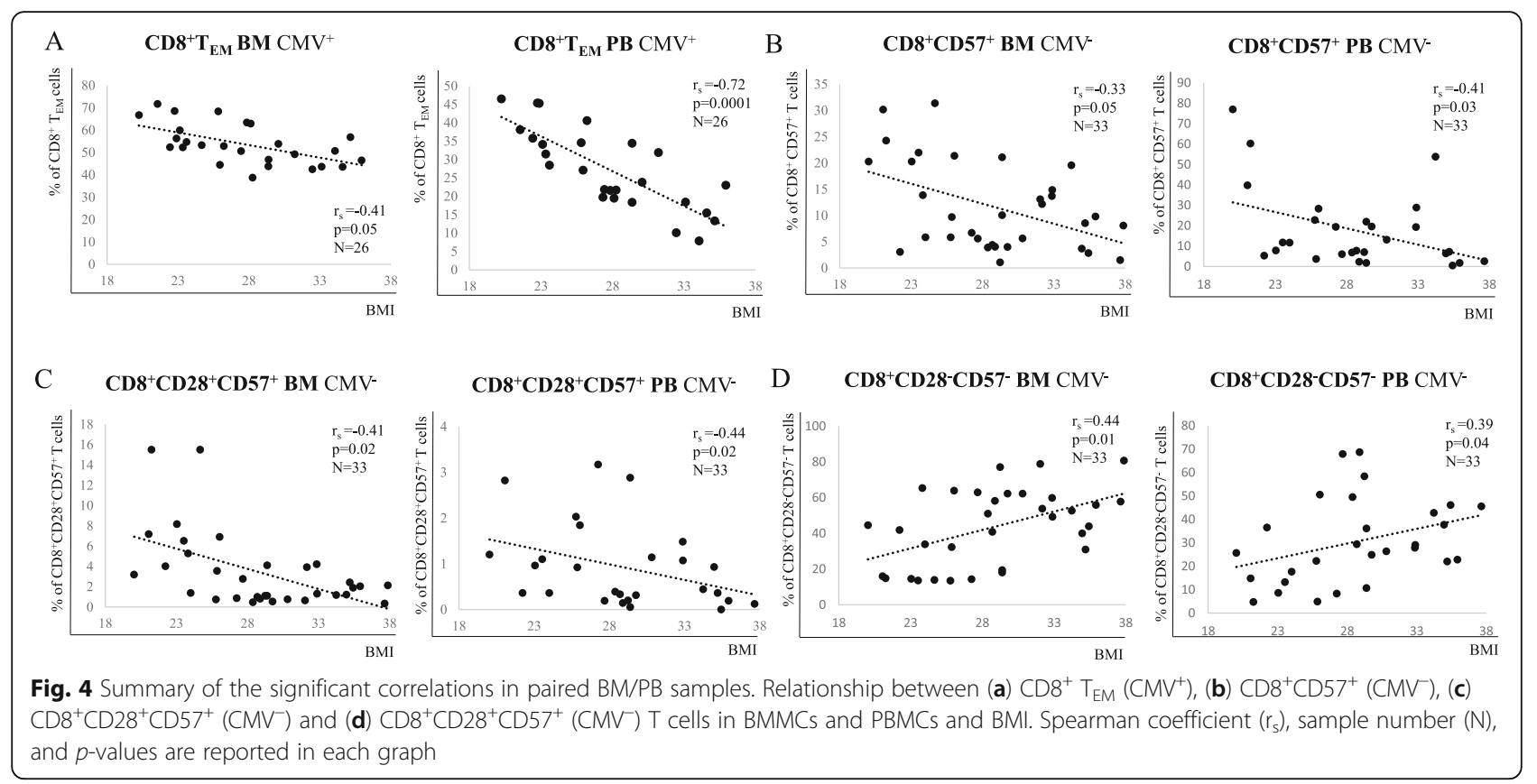

adaptive immune cells, therefore playing an important role in establishing niches for memory $\mathrm{T}$ cells and longlived plasma cells in the BM. Despite this, as MAT additionally produces pro-inflammatory molecules such as IL-6 and TNF, its accumulation may be detrimental for the maintenance of immunological memory in the BM. Indeed, reduced plasma cell function with increased numbers of adipocytes has been documented [18].

The first aim of the current study was to assess whether the BM niche environment supporting the maintenance of adaptive immune cells may change with increased BMI (Fig. 1). Although the focus of our work was not on MAT but on BMMCs, a close interaction between BM adipocytes and other BM cells is expected. Increased production of IL-15, mainly important for the survival of highly differentiated T cells, and IL-6, a pro-inflammatory molecule additionally involved in plasma cell and T cell maintenance, was found in overweight compared to lean persons. In addition, a positive correlation was found between ROS in BMMCs and $\mathrm{BMI}$, in line with the observations that obese persons are characterized by high levels of oxidative stress [3]. Increased oxygen radicals found in obese persons were linked to a decreased production of pro-inflammatory molecules by $\mathrm{CD}^{+} \mathrm{T}$ cells. Indeed, we saw a negative correlation between IFN $\gamma^{+}$and $\mathrm{TNF}^{+} \mathrm{CD}^{+} \mathrm{T}$ cells and $\mathrm{BMI}$ in the $\mathrm{BM}$, suggesting that $\mathrm{CD}^{+} \mathrm{T}$ cell effector functions in the BM may be impaired in overweight persons. This situation could be observed in the BM but not in the PB. This aspect slightly differs from the situation observed in the BM during aging [14].
Although, also in this case, an increase in the levels of IL-15, IL-6 and ROS was documented, the expression of IFNY and TNF was increased. We can speculate that, in the BM of obese persons, other factors not considered in the current study (such as adipokines or other molecules) may counteract the production of IFNY and TNF.

Another important aspect to investigate is whether the frequency of immune cell subsets in the BM change with increased BMI. For this part, the influence of CMV also needs to be considered, and therefore the samples were divided into $\mathrm{CMV}^{-}$and $\mathrm{CMV}^{+}$groups. CMV is a persisting herpes virus, which, depending on the cohort, is present in $60-100 \%$ of individuals [29, 30]. By itself, CMV has been linked to diseases and/or pathologies such as cardiovascular diseases and cancer [31-33]. More recently, we described how CMV affects the phenotype of subsets of highly differentiated $\mathrm{CD} 8^{+} \mathrm{T}$ cells in the BM [15]. After a first general definition of immune cell populations in the BM, we observed that both $\mathrm{CD} 4^{+} \mathrm{T}$ cells and $\mathrm{B}$ cells significantly increased in persons with high BMI, but only in the $\mathrm{CMV}^{-}$group. Higher frequency of both subsets in the PB of obese persons has been documented [8]. Activated $\mathrm{CD} 4^{+} \mathrm{T}$ cells accumulate in WAT of mice on high fat diet, supporting the recruitment of M1 macrophages with a proinflammatory phenotype, therefore leading to WAT inflammation [34]. Although it is still unknown whether $\mathrm{CD}^{+}{ }^{+} \mathrm{T}$ cells may additionally infiltrate into MAT, we can speculate that this subset may contribute to the onset of a pro-inflammatory environment within the 
marrow. As B cell frequency was described to correlate with BMI, further studies must be performed in order to assess whether specific B cell subsets may change with increased body weight.

As a next step, we investigated whether the phenotype of "classical" $\mathrm{CD}^{+}$and $\mathrm{CD}_{4}^{+} \mathrm{T}$ cell subsets in the $\mathrm{BM}$ may be influenced by BMI. This and the following parts were performed in both $\mathrm{BM}$ and $\mathrm{PB}$ in paired samples. Interestingly, most of the significant correlations within $\mathrm{CD}^{+} \mathrm{T}$ cell subpopulations in the $\mathrm{BM}$ were found in $\mathrm{CMV}^{-}$persons. This suggests that the $\mathrm{CMV}^{+}$group may be more homogeneous regarding $\mathrm{CD}^{+} \mathrm{T}$ cell parameters, and the effects of obesity may be more evident in $\mathrm{CMV}^{-}$persons. In alternative, in $\mathrm{CMV}^{+}$donors, the impact of CMV on the $\mathrm{T}$ cell compartment may be so profound that other more subtle changes such as BMI may be missed. $\mathrm{CD}^{+} \mathrm{T}_{\mathrm{CM}}$ and $\mathrm{CD} 8^{+} \mathrm{T}_{\mathrm{EM}}$ subsets are known to include bona fide memory cells, which are classically characterized by expression of costimulatory receptor CD28 and lack the marker of terminal differentiation CD57. Overall, our results indicate that $\mathrm{BM} \mathrm{CD8} 8^{+} \mathrm{T}_{\mathrm{CM}}$ and $\mathrm{CD}^{+} \mathrm{T}_{\mathrm{EM}}$ decreased in overweight compared to lean persons, in either the $\mathrm{CMV}^{-}\left(\mathrm{CD}^{+} \mathrm{T}_{\mathrm{CM}}\right)$ or in the $\mathrm{CMV}^{+}\left(\mathrm{CD}^{+} \mathrm{T}_{\mathrm{EM}}\right)$ groups. In addition, the frequency of IL7R $\alpha^{+} \mathrm{KLRG}^{-}{ }^{-}$MPEC, known to differentiate into memory $T$ cells $[21,22]$, was negatively associated with $\mathrm{BMI}$ in the $\mathrm{BM}$ of both $\mathrm{CMV}^{-}$and $\mathrm{CMV}^{+}$persons. Similar trends were described for the $\mathrm{PB}$, although no differences were found in the $\mathrm{CMV}^{-}$group. Altogether, these data indicate that the maintenance of memory $\mathrm{CD}^{+} \mathrm{T}$ cells in the BM may be negatively affected by body weight. In addition, it is still unknown whether MAT may be involved in the competition for space between immune cell populations in the BM, supporting the preferential accumulation of certain subsets [35, 36].

We recently reported that, using the markers CD28 and CD57, populations of non-activated/early-activated/memory $\mathrm{CD} 28^{+} \mathrm{CD} 57^{-}$, activated/immune regulatory-like $\mathrm{CD} 28^{+}$ $\mathrm{CD} 57^{+}$, activated/early-senescent $\mathrm{CD} 28^{-} \mathrm{CD} 57^{-}$and terminally differentiated/senescent-like $\mathrm{CD} 28^{-} \mathrm{CD} 57^{+}$cells could be identified within $\mathrm{CD}^{+} \mathrm{T}$ cells [37]. Although the overall amount of $\mathrm{CD} 8^{+} \mathrm{CD} 57^{+} \mathrm{T}$ cells decreased while the frequency of $\mathrm{CD} 28^{-} \mathrm{CD} 8^{+} \mathrm{T}$ cells did not change in relationship to $\mathrm{BMI}$, differences were observed when the four subsets were considered. Interestingly, both the $\mathrm{CD} 28^{+} \mathrm{CD} 57^{-}$population, which includes memory $\mathrm{CD}^{+} \mathrm{T}$ cells, and the $\mathrm{CD} 28^{+} \mathrm{CD} 57^{+}$subset, which may play an important role in regulating immune responses [37], decreased in the BM of overweight compared to lean persons in the $\mathrm{CMV}^{-}$group. Despite this, although a link between obesity and $\mathrm{T}$ cell senescence has been suggested in murine adipose tissue [38], only few senescent-like populations were influenced by body weight in our cohort, in both $\mathrm{BM}$ and $\mathrm{PB}$. In particular, while $\mathrm{CD} 28^{-} \mathrm{CD}^{-} 7^{+}$, IL7R $\alpha^{-} \mathrm{KLRG}^{+}{ }^{+}$SLEC and $\mathrm{CD} 8^{+} \mathrm{T}_{\text {EMRA }} \mathrm{T}$ cells did not change, only KLRG-1 expression positively correlated with BMI in some subsets. Despite this, it is important to consider that the expression of KLRG-1 alone may not represent an optimal marker for $\mathrm{T}$ cell senescence [39]. We can clearly observe that the frequency of $\mathrm{CD} 28^{-} \mathrm{CD} 57^{-}$ $\mathrm{CD}^{+} \mathrm{T}$ cells, which accumulates in the $\mathrm{BM}$ compared to $\mathrm{PB}$, significantly increased with body weight. Thus, we can speculate that, although the "early steps" of $\mathrm{CD} 8^{+} \mathrm{T}$ cell senescence may be triggered by obesity, the "late steps", which involve the upregulation of $\mathrm{CD} 57$, may be somehow inhibited. The reduced expression of IFN $\gamma$ and TNF by $\mathrm{CD}^{+} \mathrm{T}$ cells may partially be explained by the expansion of $\mathrm{CD} 28^{-} \mathrm{CD} 57^{-} \mathrm{CD} 8^{+} \mathrm{T}$ cells in obese individuals, as low production of both cytokines was described in this subset [37].

Furthermore, in $\mathrm{CMV}^{-}$persons, $\mathrm{PD}-1$ expression on $\mathrm{BM} \mathrm{CD}^{+} \mathrm{T}$ cell subsets is negatively associated to BMI. As this co-inhibitory molecule is expressed by activated $\mathrm{T}$ cells and inhibits their further activation (therefore making $\mathrm{T}$ cells "exhausted") [40], $\mathrm{CD}^{+} \mathrm{T}$ cells may be less activated in obese persons.

We next investigated whether some relationships could be found between phenotype of $\mathrm{CD} 4^{+} \mathrm{T}$ cell subsets and $\mathrm{BMI}$, in the $\mathrm{BM}$ and in the $\mathrm{PB}$. In this case, significant differences were obtained only in the BM, indicating that the BM environment may specifically influence $\mathrm{CD} 4^{+} \mathrm{T}$ cell parameters. Interestingly, only in $\mathrm{CMV}^{+}$persons, $\mathrm{CD}^{+} \mathrm{T}_{\mathrm{N}}$ and $\mathrm{CD}^{+} \mathrm{T}_{\mathrm{CM}}$ increased while $C D 4^{+} \mathrm{T}_{\mathrm{EM}}$ decreased in overweight persons. While $\mathrm{T}_{\mathrm{N}}$ and $\mathrm{T}_{\mathrm{CM}}$ are stable, $\mathrm{T}_{\mathrm{EM}}$ cells are known to display rapid turnover [41]. Thus, our data suggest that, in obese $\mathrm{CMV}^{+}$individuals, the maintenance of naive and longlived memory $\mathrm{CD} 4^{+} \mathrm{T}$ cells in the BM may be improved. Whether this aspect may be linked with the expansion of MAT observed with increased body weight must be investigated in future studies. As observed for $\mathrm{CD}^{+} \mathrm{T}$ cells, the effector functions of $\mathrm{BM} \mathrm{CD} 4^{+} \mathrm{T}$ cells may be impaired with obesity, as reduced expression of activation/exhaustion marker PD-1 could be observed. Although the levels of $\mathrm{BM} \mathrm{CD} 4^{+} \mathrm{T}_{\text {EMRA }}$ positively correlated with BMI in the whole cohort, other senescent-like $\mathrm{CD} 4^{+} \mathrm{T}$ cell subsets were not associated with body weight. Indeed, no correlations were observed when the markers CD28 and CD57 were considered.

\section{Conclusion}

Our study describes for the first time that the maintenance of memory $\mathrm{T}$ cell subsets in the BM may change in relationship to BMI. Thus, in addition to aging and CMV, BMI represents a further parameter to consider, particularly when the phenotype of effector/memory $\mathrm{T}$ cells is studied. Metabolic interventions must be planned, in order to assess whether the situation described in overweight persons may be reversible, therefore improving the fitness of adaptive immune cells. 


\section{Supplementary information}

Supplementary information accompanies this paper at https://doi.org/10. 1186/s12979-020-00186-w.

\section{Additional file 1.}

Additional file 2.

\section{Abbreviations}

BMl: body mass index; PB: peripheral blood; PBMC: PB mononuclear cells; BM: bone marrow; BMMCs: BM mononuclear cells; ROS: reactive oxygen species

\section{Acknowledgements}

The authors thank Dr. Klemens Trieb (Wels, Austria) for providing the samples.

\section{Authors' contributions}

LP designed the study, performed experiments, analysed data and wrote the paper. EN, CM and MK performed experiments, JCA analysed data, BGL and BW contributed to the study design. The author(s) read and approved the final manuscript.

\section{Funding}

The research leading to these results received funding from the European Union's Seventh Framework Programme [FP7/2007-2013] under Grant Agreement No: 280873 ADITEC, the Austrian Science Fund (FWF; doctoral programme HOROS, W1253), and by the EU H2020 project "An integrated approach to dissect determinants, risk factors, and pathways of ageing of the immune system" (ImmunoAgeing, H2020-PHC-2014 grant agreement No: 633964).

\section{Availability of data and materials}

All datasets and material are available upon request.

\section{Ethics approval and consent to participate}

Study approval was given by the local institution, and written informed consent was received from all participants prior to their inclusion in the study in accordance with the Declaration of Helsinki.

\section{Consent for publication}

All authors gave the consent for publication.

\section{Competing interests}

The authors declare no commercial or financial conflict of interest.

\section{Author details}

'Department of Immunology, Institute for Biomedical Aging Research, University of Innsbruck, Rennweg, 10 Innsbruck, Austria. ${ }^{2}$ Present Address: Center for Mind/Brain Sciences (CIMeC), University of Trento, Corso Bettini, 31 Rovereto, Italy. ${ }^{3}$ Present Address: Private Kinderwunsch-Clinic Dr. J. Zech $\mathrm{GmbH}$, Grabenweg 64, 6020 Innsbruck, Austria.

Received: 3 February 2020 Accepted: 18 May 2020

Published online: 27 May 2020

\section{References}

1. T.T. Sarnali, Md PK Moyenuddin. Obesity and Disease Association: A Review Anwer Khan Modern Med College J 2010; (2), 21-24.

2. Matarese $G$, Procaccini C, De Rosa C, Horvath TL, La Cava A. Regulatory T cells in obesity: the leptin connection. Trends Mol Med. 2010;16(6):247-56.

3. Marseglia L, Manti S, D'Angelo G, Nicotera A, Parisi E, Di Rosa G, Gitto E, Arrigo T. Oxidative stress in obesity: a critical component in human diseases. Int J Mol Sci. 2014;16(1):378-400.

4. Hotamisligil GS. Inflammation and metabolic disorders. Nature. 2006; 444(7121):860-7.

5. Symonds ME, Sebert SP, Hyatt MA, Budge H. Nutritional programming of the metabolic syndrome. Nat Rev Endocrinol. 2009:5(11):604-10.

6. Francisco V, Pino J, Campos-Cabaleiro V, Ruiz-Fernández C, Mera A, Gonzalez-Gay MA, Gómez R, Gualillo O. Obesity, Fat Mass and Immune System: Role for Leptin. Front Physiol. 2018;9:640
7. Maury E, Brichard SM. Adipokine dysregulation, adipose tissue inflammation and metabolic syndrome. Mol Cell Endocrinol. 2010;314(1):1-16.

8. Ilavská S, Horváthová M, Szabová M, Nemessányi T, Jahnová E, Tulinská J, Lišková A, Wsolová L, Staruchová M, Volkovová K. Association between the human immune response and body mass index. Hum Immunol. 2012;73(5): 480-5.

9. Tokoyoda K, Zehentmeier S, Hegazy AN, Albrecht I, Grun JR, Lohning M, Radbruch A. Professional memory CD4+ T lymphocytes preferentially reside and rest in the bone marrow. Immunity. 2009;30:721-30.

10. Becker TC, Coley SM, Wherry EJ, Ahmed R. Bone marrow is a preferred site for homeostatic proliferation of memory CD8 T cells. J Immunol. 2005;174: 1269-73.

11. Herndler-Brandstetter $D$, Landgraf $K$, Jenewein $B$, Tzankov A, Brunauer $R$, Brunner S, Parson W, Kloss F, Gassner R, Lepperdinger G, GrubeckLoebenstein B. Human bone marrow hosts polyfunctional memory CD4+ and CD8+ T cells with close contact to IL-15-producing cells. J Immunol. 2011;186:6965-71

12. Collins N, Han SJ, Enamorado M, Link VM, Huang B, Moseman EA, Kishton RJ, Shannon JP, Dixit D, Schwab SR, Hickman HD, Restifo NP, McGavern DB, Schwartzberg PL, Belkaid Y. The Bone Marrow Protects and Optimizes Immunological Memory during Dietary Restriction. Cell. 2019;178(5):1088101 e15.

13. A. Okhrimenko, J.R. Grün, K. Westendorf, Z. Fang, S. Reinke, P. von Roth P, G. Wassilew, A.A. Kühl, R. Kudernatsch, S. Demski, C. Scheibenbogen, K. Tokoyoda, M.A. McGrath, M.J. Raftery MJ, G. Schönrich, A. Serra, H.D. Chang, A. Radbruch, J. Dong. Human memory T cells from the bone marrow are resting and maintain long-lasting systemic memory. Proc Natl Acad Sci U S A 2014;111(25):9229-9234.

14. Pangrazzi L, Meryk A, Naismith E, Koziel R, Lair J, Krismer M, Trieb K. B. Grubeck- Loebenstein."Inflamm-aging" influences immune cell survival factors in human bone marrow. Eur J Immunol. 2017;47(3):481-92.

15. Pangrazzi L, Naismith E, Meryk A, Keller M, Jenewein B, Trieb K, GrubeckLoebenstein B. Increased IL-15 Production and Accumulation of Highly Differentiated CD8+ Effector/Memory T Cells in the Bone Marrow of Persons with Cytomegalovirus. Front Immunol. 2017:8:715.

16. Lee M-J, Wu Y, Fried SK. Adipose tissue heterogeneity: implication of depot differences in adipose tissue for obesity complications. Mol Asp Med. 2013; 34:1-11.

17. Galic S, Oakhill JS, Steinberg GR. Adipose tissue as an endocrine organ. Mol Cell Endocrinol. 2010;316:129-39.

18. Miggitsch C, Meryk A, Naismith E, Pangrazzi L, Ejaz A, Jenewein B, Wagner S, Nägele F, Fenkart G, Trieb K, Zwerschke W, Grubeck-Loebenstein B. Human bone marrow adipocytes display distinct immune regulatory properties. EBioMedicine. 2019;46:387-98.

19. Styner M, Thompson WR, Galior K, Uzer G, Wu X, Kadari S, Case N, Xie Z, Sen B, Romaine A, Pagnotti GM, Rubin CT, Styner MA, Horowitz MC, Rubin J. Bone marrow fat accumulation accelerated by high fat diet is suppressed by exercise. Bone. 2014;64:39-46.

20. Freeman GI, Long AJ, Iwai Y, Bourque $K$, Chernova T, Nishimura H, Fitz LJ, Malenkovich N, Okazaki T, Byrne MC, Horton HF, Fouser L, Carter L, Ling V, Bowman MR, Carreno BM, Collins M, Wood CR, Honjo T. Engagement of the PD-1 immunoinhibitory receptor by a novel B7 family member leads to negative regulation of lymphocyte activation. J Exp Med. 2000;192(7):1027-34.

21. Joshi NS, Cui W, Chandele A, Lee HK, Urso DR, Hagman J, Gapin L, Kaech SM. Inflammation directs memory precursor and short-lived effector CD8(+) $T$ cell fates via the graded expression of T-bet transcription factor. Immunity. 2007:27(2):281-95

22. Remmerswaal EBM, Hombrink P, Nota B, Pircher H, Ten Berge IJM, van Lier RAW, van Aalderen MC. Expression of IL-7Ra and KLRG1 defines functionally distinct CD8(+) T-cell populations in humans. Eur J Immunol. 2019 May; 49(5):694-708

23. Koch S, Larbi A, Derhovanessian E, Ozcelik D, Naumova E, Pawelec G. Multiparameter flow cytometric analysis of CD4 and CD8 T cell subsets in young and old people. Immun Ageing. 2008:5:6.

24. Wilding JPH. Should obesity be recognised as a disease? BMJ. 2019;366: 14258.

25. Kohlgruber AC, LaMarche NM, Lynch L. Adipose tissue at the nexus of systemic and cellular immunometabolism. Semin Immunol. 2016;28:431-40.

26. Wensveen FM, Valentic S, Sestan M, Wensveen TT, Polic B. Interactions between adipose tissue and the immune system in health and malnutrition. Semin Immunol. 2015;27:322-33. 
27. Han SJ, Glatman Zaretsky A, Andrade-Oliveira V, Collins N, Dzutsev A, Shaik J, Morais da Fonseca D, Harrison OJ, Tamoutounour S, Byrd AL, Smelkinson M, Bouladoux N, Bliska JB, Brenchley JM, Brodsky IE, Belkaid Y. White adipose tissue is a reservoir for memory t cells and promotes protective memory responses to infection. Immunity. 2017;47:1154-68 e6.

28. Eberl G, Colonna M, Di Santo JP, McKenzie AN. Innate lymphoid cells. Innate lymphoid cells: a new paradigm in immunology. Science. 2015;348:aaa6566.

29. Hengel H, Brune W, Koszinowski UH. Immune evasion by cytomegalovirus survival strategies of a highly adapted opportunist. Trends Microbiol. 1998; 6(5):190-7.

30. Pawelec G, Derhovanessian E. Role of CMV in immune senescence. Virus Res. 2011;157:175-9.

31. Simanek AM, Dowd JB, Pawelec G, Melzer D, Dutta A, Aiello AE. Seropositivity to cytomegalovirus, inflammation, all-cause and cardiovascular disease-related mortality in the United States. PLoS One. 2011;6(2):e16103.

32. Nieto FJ, Adam E, Sorlie P, Farzadegan H, Melnick JL, Comstock GW, Szklo M. Cohort study of cytomegalovirus infection as a risk factor for carotid intimal-medial thickening, a measure of subclinical atherosclerosis. Circulation. 1996;94:922-7.

33. Samanta M, Harkins L, Klemm K, Britt WJ, Cobbs CS. High prevalence of human cytomegalovirus in prostatic intraepithelial neoplasia and prostatic carcinoma. J Urol. 2003:170:998-1002.

34. Kintscher U, Hartge M, Hess K, Foryst-Ludwig A, Clemenz M, Wabitsch M, Fischer-Posovszky P, Barth TFE, Dragun D, Skurk T, Hauner H, Blüher M, Unger T, Wolf A-M, Knippschild U, Hombach V, Marx N. T-lymphocyte infiltration in visceral adipose tissue: a primary event in adipose tissue inflammation and the development of obesity-mediated insulin resistance. Arterioscler Thromb Vasc Biol. 2008;28:1304-10.

35. Naismith E, Pangrazzi L, Grasse M, Keller M, Miggitsch C, Weinberger B, Trieb K, Grubeck-Loebenstein B. Peripheral antibody concentrations are associated with highly differentiated $T$ cells and inflammatory processes in the human bone marrow. Immun Ageing. 2019;16:21.

36. Naismith $E$, Pangrazzi L. The impact of oxidative stress, inflammation, and senescence on the maintenance of immunological memory in the bone marrow in old age. Biosci Rep. 2019;14:39(5).

37. L. Pangrazzi, J. Reidla, J.A. Carmona Arana, E. Naismith, C. Miggitsch, A. Meryk, M. Keller, A.A.N Krause, F.L. Melzer, K. Trieb, M. Schirmer, B. GrubeckLoebenstein, B. Weinberger. CD28 and CD57 define four populations with distinct phenotypic properties within human CD8(+) T cells. Eur J Immunol 2019; 0: 1-17

38. Shirakawa K, Yan X, Shinmura K, Endo J, Kataoka M, Katsumata Y, Yamamoto T, Anzai A, Isobe S, Yoshida N, Itoh H, Manabe I, Sekai M, Hamazaki Y, Fukuda K, Minato N, Sano M. Obesity accelerates T cell senescence in murine visceral adipose tissue. J Clin Invest. 2016;126(12):4626-39.

39. Henson SM, Akbar AN. KLRG1--more than a marker for T cell senescence. Age (Dordr). 2009;31 (4):285-91.

40. Jin HT, Ahmed R, Okazaki T. Role of PD-1 in regulating T-cell immunity. Curr Top Microbiol Immunol. 2011;350:17-37.

41. Macallan DC, Wallace D, Zhang Y, De Lara C, Worth AT, Ghattas H, Griffin GE, Beverley PC, Tough DF. Rapid turnover of effector-memory CD4(+) T cells in healthy humans. J Exp Med. 2004;200(2):255-60.

\section{Publisher's Note}

Springer Nature remains neutral with regard to jurisdictional claims in published maps and institutional affiliations.

\section{Ready to submit your research? Choose BMC and benefit from}

- fast, convenient online submission

- thorough peer review by experienced researchers in your field

- rapid publication on acceptance

- support for research data, including large and complex data types

- gold Open Access which fosters wider collaboration and increased citations

- maximum visibility for your research: over $100 \mathrm{M}$ website views per year

At $\mathrm{BMC}$, research is always in progress.

Learn more biomedcentral.com/submissions 